\title{
Marwit Rod El Leqah Quartz Deposits as a Strategic Source of High Purity Quartz
}

\author{
Suzan S. Ibrahim¹, Mohamed G. Shahien², Ali Q. Seliem², Mostafa R. Abukhadra2*, \\ Ahmed M. Zayed ${ }^{2}$ \\ ${ }^{1}$ Central Metallurgical R \& D Institute, Helwan, Egypt \\ ${ }^{2}$ Geology Department, Faculty of Science, Beni-Suif University, Cairo, Egypt \\ Email: Geomostafa89@yahoo.com
}

Received 6 August 2015; accepted 22 September 2015; published 25 September 2015

Copyright $@ 2015$ by authors and Scientific Research Publishing Inc.

This work is licensed under the Creative Commons Attribution International License (CC BY). http://creativecommons.org/licenses/by/4.0/

(c) (i) Open Access

\begin{abstract}
Evaluation of Marwit Rod El Leqah deposit as pegmatite high purity quartz source for advanced applications was conducted through the geological, mineralogical and geochemical studies. Elemental analysis of a representative quartz sample showed that the quartz deposits were classified as medium purity quartz with $99.575 \%$ average $\mathrm{SiO}_{2}$ content and about $0.422 \%(4220 \mathrm{ppm})$ of accompanied mineral. Field study and petrography investigation using optical polarized transmitted microscope and reflected light microscope revealed that these impurities were mainly found as solid particulates of iron oxide, muscovite, rutile, orthoclase, granitic rafts, and as fluid inclusions as well. Moreover, structural undesirable trace elements were also presented in the quartz sample.
\end{abstract}

\section{Keywords}

Pegmatite Quartz, Advanced Applications, Solid Impurities, Structural Impurities

\section{Introduction}

The world demand of quartz is increasing gradually, in particular, high purity quartz [1] [2]. Industrial agencies forecast a solid 5\% - 20\% annual growth in high quality quartz demand for high-tech applications like semiconductors, high temperature lamp tubing, telecommunications and optics, microelectronics, and solar silicon applications [3]-[5]. High purity quartz is characterized by containing less than $50 \mathrm{ppm}$ impurities [6]. High purity quartz can be formed under special geological conditions where a narrow set of chemical and physical parameters have been fulfilled. According to the geological conditions at the time of formation, quartz often contains fluid and/or mineral inclusions and structural impurities as well [7]-[10]. Previous studies reveal that the con-

${ }^{*}$ Corresponding author.

How to cite this paper: Ibrahim, S.S., Shahien, M.G., Seliem, A.Q., Abukhadra, M.R. and Zayed, A.M. (2015) Marwit Rod El Leqah Quartz Deposits as a Strategic Source of High Purity Quartz. Journal of Geoscience and Environment Protection, 3, 41-47. http://dx.doi.org/10.4236/gep.2015.37005 
centrations of trace element impurities in quartz from low temperature geological setting are lower than those from high temperature geological settings [11].

In conclusion, pegmatite quartz, metamorphogenically mobilized quartz veins and lenses as well as some hydrothermal quartz veins have the greatest potential for high-purity quartz raw materials. In Egypt, the main quartz deposits are located in the western regions of the Arabian platform within the central and southern parts of the Eastern Desert. Egyptian geological survey (1992) recorded a total of 37 quartz bodies under exploration and 20 new quartz sites scattered in the central area of the Eastern Desert between Quift-Quseir road in the north and Idfu-Mars Alam road in the south [12]. These quartz deposits are shaped as lens and as series of veins, genetically and spatially associated with granodioritic, granitic and tonalitic intrusions. Unfortunately, such deposits have not been completely studied to determine their suitability for high-tech industries. Therefore, the aim of this search is to study the amenability of Marwit Rod El Leqah quartz for high technical applications based on detailed mineralogy and geochemistry investigations.

\section{Experimental Work}

Macroscopic evaluation for the quartz body of the study area was done through geological field trips to detect the major sources of contaminations. Chemical composition for representative quartz samples was obtained by XRF analysis using the Pnalytical Axios Advanced XRF technique, was carried out at The Central Metallurgical Research and Development, Egypt. Petrographic investigations performed by Nicon transmitted polarized microscope attached with computer program analysis to identify various impurities, their sizes, occurrence and their distribution.

\section{Results}

\subsection{Geological Setting}

The area under investigation is situated in the central part of the Eastern Desert to the west of Marsa Alam-Idfusphaltic road, at the intersection of $24^{\circ} 25^{\prime} 28^{\prime \prime}$ and longitude $34^{\circ} 08^{\prime} 27^{\prime \prime}$. The geological map of the quartz deposits of this area (Figure 1), reveals that, the area is occupied by acidic and basic rocks which classified as alkali

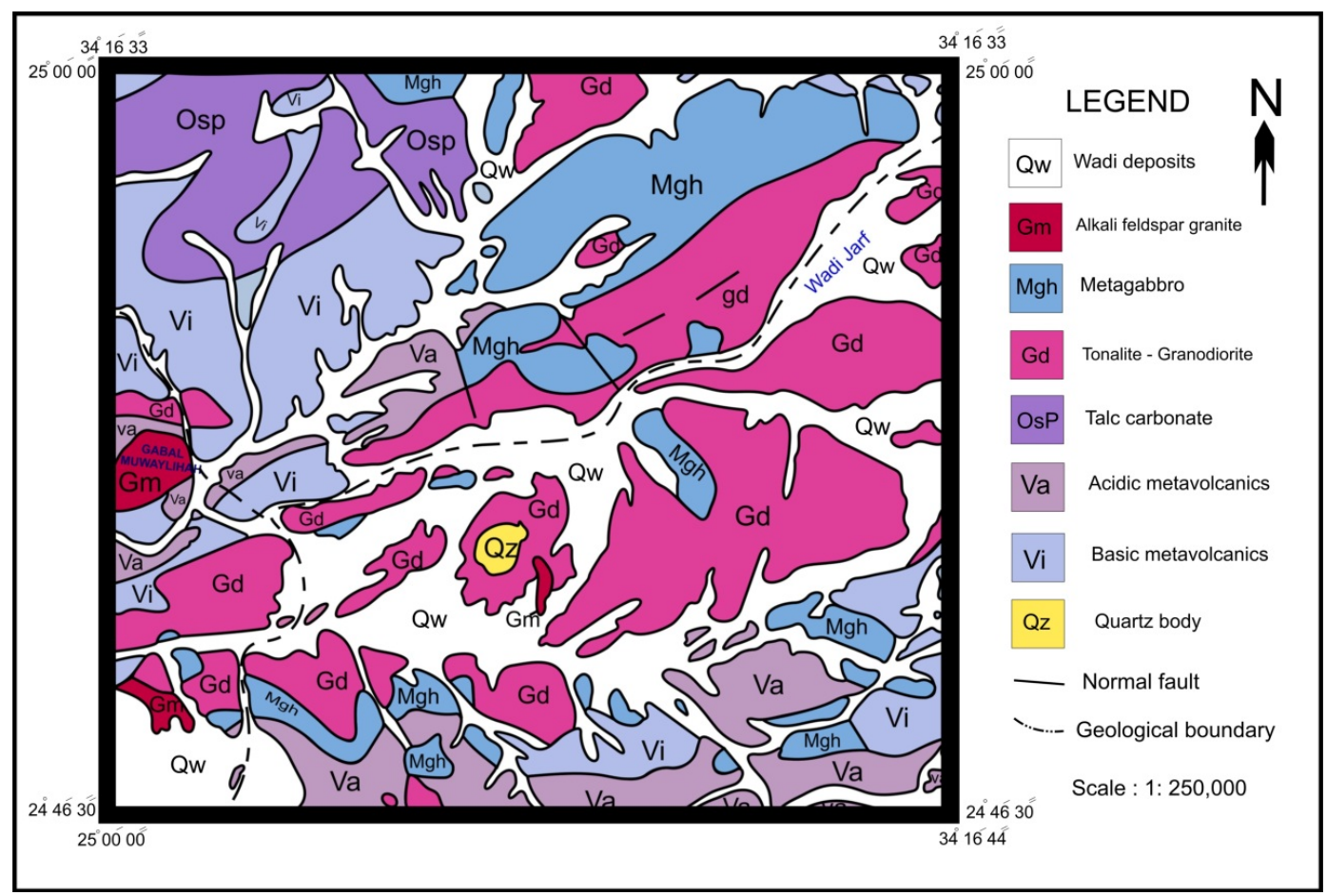

Figure 1. General geological map of Marwit Rod El Leqah quartz deposit area, Idfumars Alam Road, central eastern desert, Egypt (modified after Ezzeldin, 2007). 
feldspar granite, tonalite, granodiorite, also metamorphosed rocks as metagabbro, metavolcanicsand talc carbonate rocks. The dimensions of the quartz body were calculated by Dam Company as $200 \mathrm{~m}$ (length), $200 \mathrm{~m}$ (width), and $70 \mathrm{~m}$ (height), which meet the geological reserves (about 7,420,000 tons).

This area is hosted by granitic pluton that caps its upper part (Figure 2(A)). The country rock of the quartz body seems to be very altered and fractured pale pink granite (Figure 2(B)). The granite outcrop formed the hill of Marwit Rod El Leqah and the low level around. Petrographically, the granitic host rock composed essentially of plagioclase ( $44.0 \%$ to $50.7 \%$ ), quartz (28.0\% to $35.59 \%$ ), mica (biotite commonly altered to muscovite from $7.0 \%$ to $7.7 \%)$, and alkali feldspars (14.0\% to $15.5 \%)$. It was classified according to the International Union of Geological Science (IUGS) of granitic and allied rocks based upon modal composition in volume \% as granodiorite.

The area of the deposits is traversed by dykes range from acidic to basic composition. Quartz mineral was

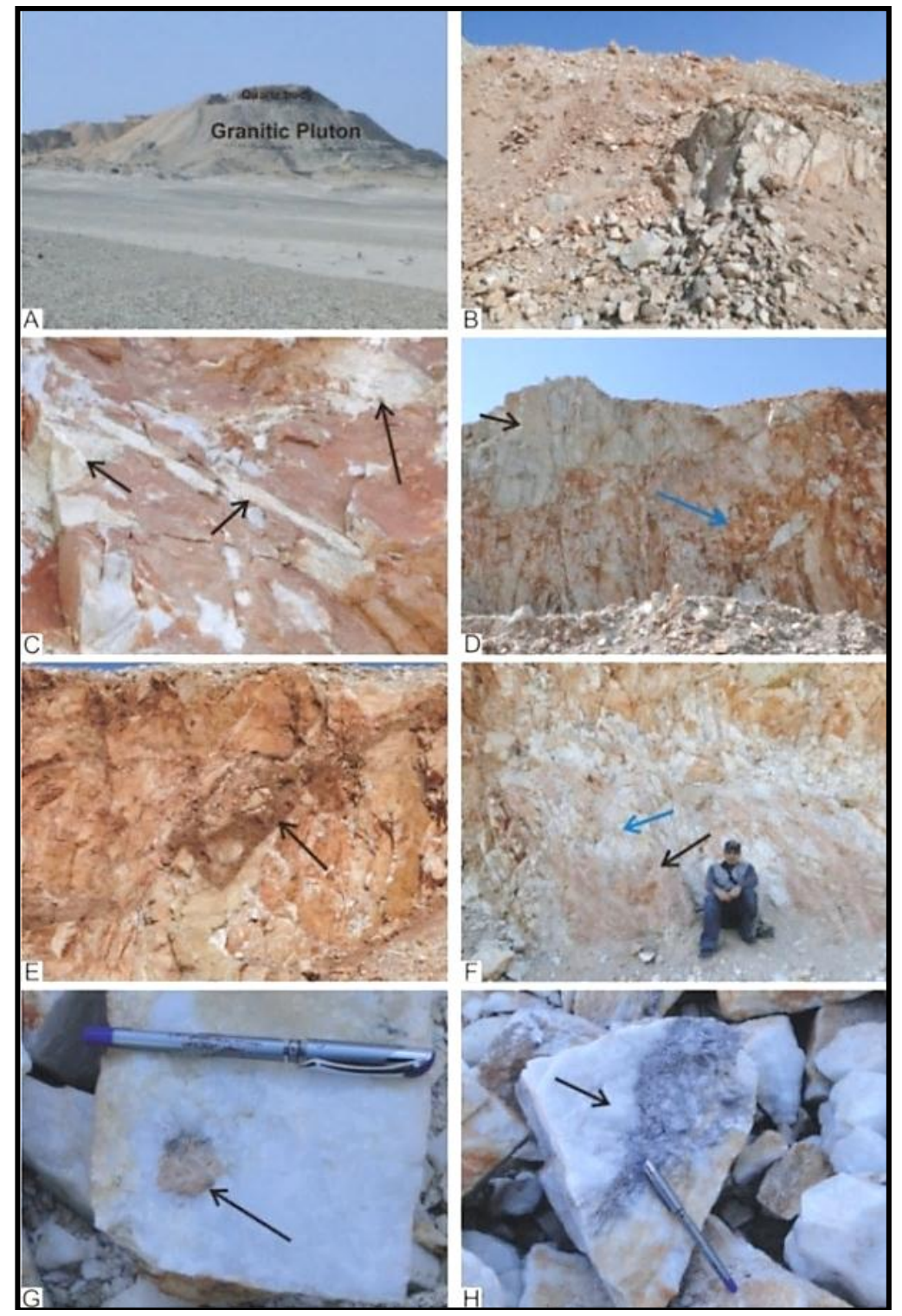

Figure 2. Shows (A) General view of Rod El Leqah quartz body capping granitic pluton; (B) Pale pink granite host rock; (C) Rafts from granite enclosed within quartz body; (D) Extraction face of quartz appears in milky white color and change to red due to iron oxide staining along fractures and fissures (blue arrow); (E) Lensoidal sheet of iron oxide within highly deformed zone in the quartz body (black arrow); (F) Mélange of quartz and feldspars (black arrow); (G) Xenocryst of feldspar within quartz fragments; $(\mathrm{H})$ Opaque minerals and mica associated with the quartz body. 
shown to be cut through the granitic host as veins with sharp contact and commonly encloses rafts (Figure 2(C)). The quartz body was appeared milky white in color with highly fractured feature; and sometimes it changes to reddish white color due to iron staining especially along fractures (Figure 2(D)). The deposit contained lensoidal sheets of iron oxide or altered granite enriched in iron oxide (Figure 2(E)), that may formed as a result of hydrothermal alteration of granitic rafts enclosed to the quartz body. Such alterations were occurred due to the liberation of iron oxide from biotite minerals that were found in the granite rocks. Quartz sometimes occurred as patches, veinlets inside the feldspar intercalated with it (Figure 2(F)). Crystals of feldspars were mainly found as orthoclases that were observed inside quartz masses (Figure 2(G)). Other opaque minerals are detected in some places (Figure 2(H)).

\subsection{Petrographic Investigation of the Samples}

Petrography investigation of original samples using transmitted polarizing microscope revealed that the quartz samples were consisted of subhedral to anhedral interlocked quartz crystals with particle size ranged from $<20$ $\mu \mathrm{m}$ to about $1200 \mu \mathrm{m}$ (Figure 3(A)). The quartz samples showed to entrap impurities of solid, silicate melt and fluid inclusions. Solid inclusions were mainly iron oxide, mica, rutile, and opaque minerals (in a decreasing order of abundance).

Iron oxide occurred either as accumulations enclosed within quartz crystals, in size reached about $150 \mu \mathrm{m}$ (Figure 3(B)), or as micro fractures fillings, in size range from $10 \mu \mathrm{m}$ to $150 \mu \mathrm{m}$ (Figure 3(C)). Iron oxides were shown also as concentrates along the quartz grain boundaries and sometimes they coated the quartz grains surfaces, in size range from about $3 \mu \mathrm{m}$ to $10 \mu \mathrm{m}$ (Figure 3(D)). Muscovite impurities were found either as minute
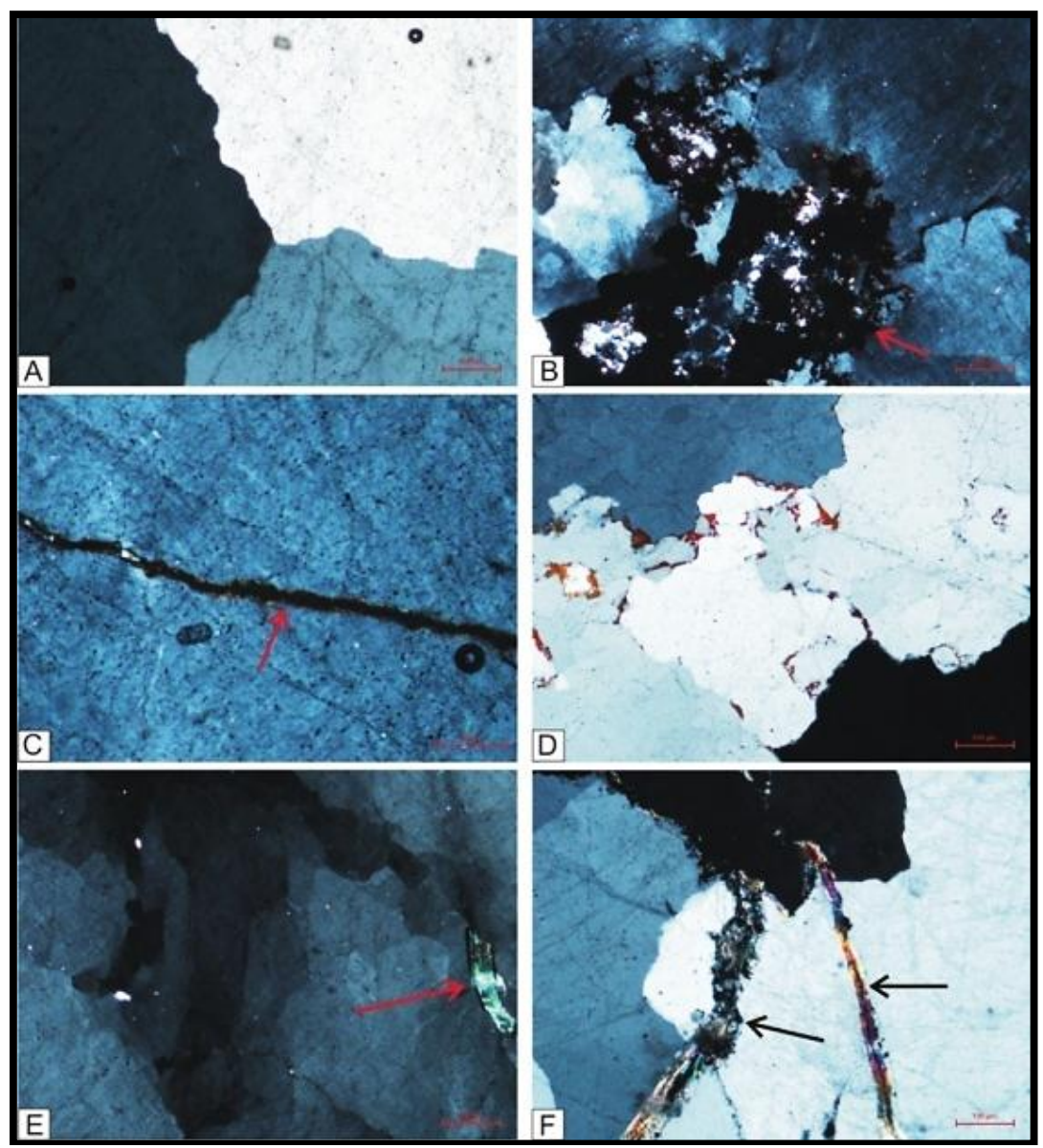

Figure 3. Shows (A) Interlocked quartz crystals with irregular grain boundaries; (B) Iron oxide impurities occluded by quartz crystal; (C) Iron oxide filling fractures within quartz crystal; (D) Iron oxide concentrates along grain boundaries and coating the quartz grain; (E) Muscovite crystal occluded by quartz; (F) Muscovite filling micro fractures within quartz crystals. 
inclusions inside the quartz crystals, in size range from $<20 \mu \mathrm{m}$ to $50 \mu \mathrm{m}$ (Figure $3(\mathrm{E})$ ), or as micro fractures filling with size range from 10 to $120 \mu \mathrm{m}$ (Figure $3(\mathrm{~F})$ ). Sometimes they presented along the quartz grain boundaries in the form of micro-crystals with size range from $10 \mu \mathrm{m}$ to $100 \mu \mathrm{m}$ (Figure 4(A)).

Muscovite crystals were commonly replaced by opaque minerals like hematite or magnetite or both (Figure 4(B)). Polished sections investigation using the reflected polarizing microscope identified opaque minerals like mica as dark color grains along the fractures cut across quartz crystals (Figure $4(C)$ ). Hematite contaminations observed as opaque micro fractures filling inside the quartz crystals, reached $10 \mu \mathrm{m}$ in size (Figure 4(D), Figure 5).

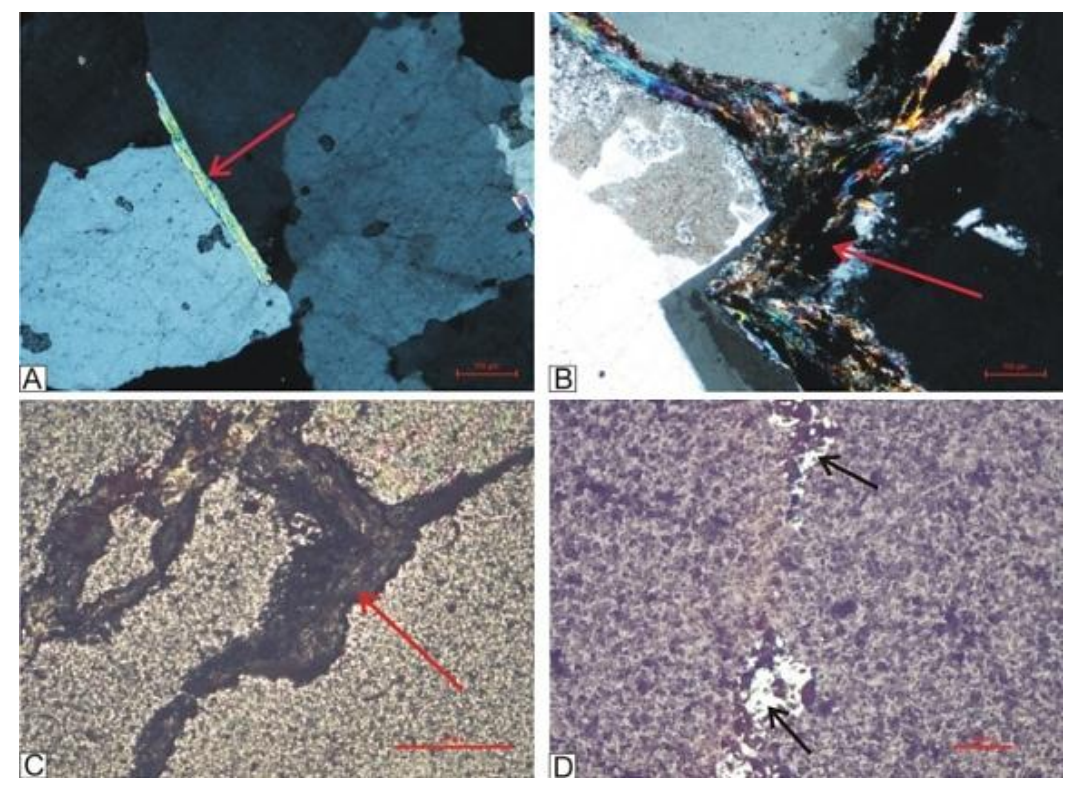

Figure 4. Shows (A) Muscovite crystals present along grain boundaries; (B) Alteration of muscovite to opaque iron oxide minerals; (C) Mica; (M) Filling fractures within quartz (Qz), notice alteration to iron oxide (blue arrow); (D) Hematite; (H) minerals within quartz.

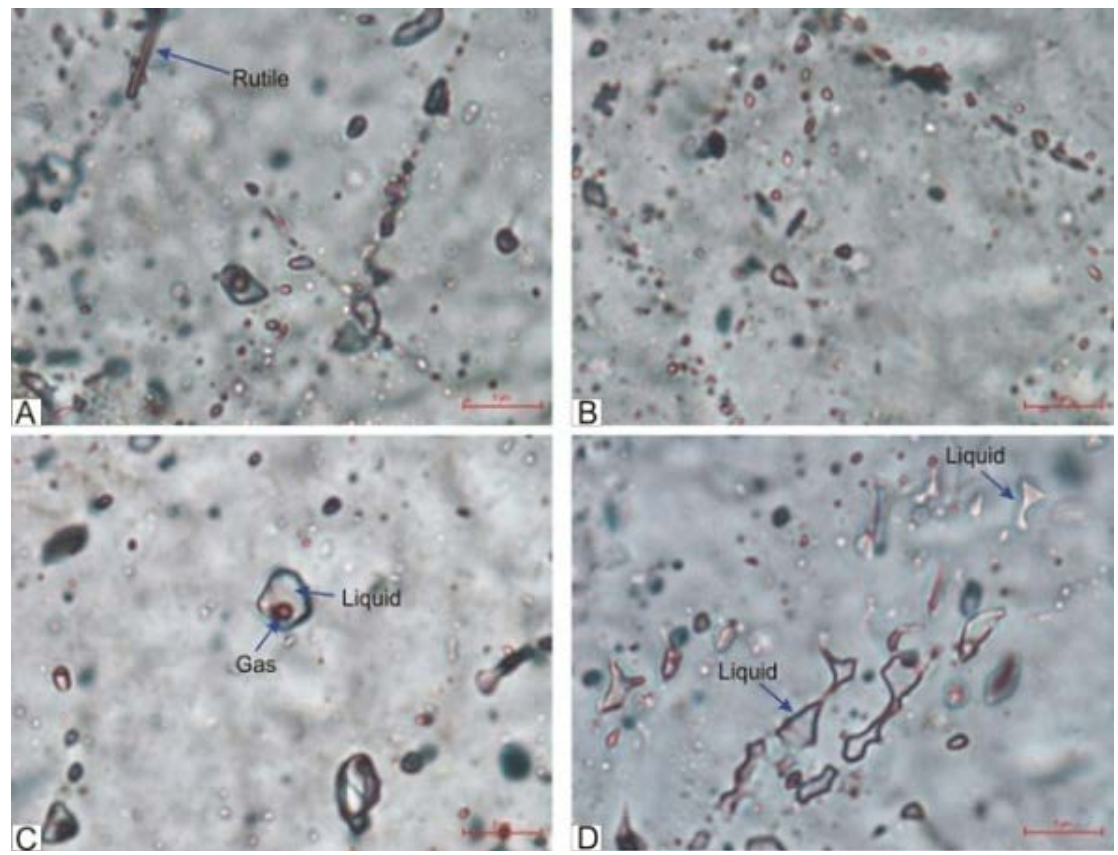

Figure 5. Shows (A) rutile crystal (blue arrow); (B) Parallel orientations of the fluids; (C) Fluid inclusion composed of two phases (liquid and gas); (D) Fluid inclusion of only liquid phase. 
Rutile minerals were observed as submicron needle shaped inclusions with diameter less than $1 \mu \mathrm{m}$ and $5 \mu \mathrm{m}$ in length (Figure 5(A)). Most of the fluid inclusions were investigated as trails with varying orientations (Figure 5(B)). Other fluid inclusions detected in random orientation inside the quartz crystals. These fluid inclusions were commonly composed of two phases, liquid phase and gaseous phase, (Figure 5(C)), but other fluids were found only in liquid phase (Figure 5(D)). Fluid inclusions were found mainly $<5 \mu \mathrm{m}$ in size and they were the reason for giving the quartz its dusty appearance.

\subsection{Chemical Analysis}

Chemical composition of representative samples from Marwit Rod El Leqah quartz deposit was determined using Phillips PW1480 spectrometer equipped with an Sc/W X-ray tube. The XRF analysis showed high silica content (99.57\%), low $\mathrm{Fe}_{2} \mathrm{O}_{3}(0.0126 \%)$ and low $\mathrm{Al}_{2} \mathrm{O}_{3}(0.085 \%)$. Also there were minor $\mathrm{CaO}, \mathrm{Na}_{2} \mathrm{O}$ and $\mathrm{K}_{2} \mathrm{O}$ contents $(<0.01 \%)$. There were also low concentrations of other trace elements (Table 1$)$.

Table 1. XRF analysis of six quartz samples.

\begin{tabular}{|c|c|c|c|c|c|c|}
\hline S.No & R1 & R2 & R3 & R4 & R5 & R6 \\
\hline $\mathrm{SiO}_{2}$ & 99.54 & 99.55 & 99.62 & 99.55 & 99.63 & 99.56 \\
\hline $\mathrm{TiO}_{2}$ & $<0.01$ & $<0.01$ & $<0.01$ & $<0.01$ & $<0.01$ & $<0.01$ \\
\hline $\mathbf{A l}_{2} \mathbf{O}_{3}$ & 0.12 & 0.07 & 0.08 & 0.08 & 0.07 & 0.09 \\
\hline $\mathrm{Fe}_{2} \mathrm{O}_{3}$ & 0.016 & 0.018 & 0.014 & 0.018 & 0.015 & 0.016 \\
\hline MnO & $<0.01$ & $<0.01$ & $<0.01$ & $<0.01$ & $<0.01$ & $<0.01$ \\
\hline MgO & $<0.01$ & $<0.01$ & $<0.01$ & $<0.01$ & $<0.01$ & $<0.01$ \\
\hline $\mathrm{CaO}$ & $<0.01$ & $<0.01$ & $<0.01$ & $<0.01$ & $<0.01$ & $<0.01$ \\
\hline $\mathrm{Na}_{2} \mathrm{O}$ & $<0.01$ & $<0.01$ & $<0.01$ & $<0.01$ & $<0.01$ & $<0.01$ \\
\hline $\mathbf{K}_{2} \mathbf{O}$ & $<0.01$ & $<0.01$ & $<0.01$ & $<0.01$ & $<0.01$ & $<0.01$ \\
\hline $\mathbf{P}_{2} \mathbf{O}_{5}$ & 0.01 & 0.01 & 0.01 & 0.01 & 0.01 & 0.01 \\
\hline L.O.I & 0.12 & 0.20 & 0.18 & 0.14 & 0.13 & 0.19 \\
\hline \multicolumn{7}{|c|}{ Trace elements (ppm) } \\
\hline $\mathbf{V}$ & $<1$ & $<1$ & $<1$ & $<1$ & $<1$ & $<1$ \\
\hline $\mathrm{Cr}$ & 2 & 4 & 5 & 4 & 5 & 3 \\
\hline Co & 4 & 5 & 5 & 4 & 4 & 5 \\
\hline $\mathbf{N i}$ & 3 & 9 & 3 & 5 & 5 & 5 \\
\hline $\mathrm{Cu}$ & 6 & 10 & 3 & 6 & 7 & 6 \\
\hline $\mathrm{Zn}$ & 2 & 9 & 6 & 5 & 4 & 6 \\
\hline Ga & $<1$ & $<1$ & $<1$ & $<1$ & $<1$ & $<1$ \\
\hline As & $<1$ & $<1$ & $<1$ & $<1$ & $<1$ & $<1$ \\
\hline $\mathrm{Sr}$ & $<1$ & $<1$ & $<1$ & $<1$ & $<1$ & $<1$ \\
\hline $\mathrm{Zr}$ & 5 & 4 & 5 & 4 & 4 & 5 \\
\hline Mo & 2 & $<1$ & 2 & 2 & 2 & 2 \\
\hline Sn & 2 & 3 & 2 & 3 & 3 & 3 \\
\hline Sb & 1 & 2 & 1 & 1 & 1 & 1 \\
\hline Ba & $<1$ & $<1$ & $<1$ & $<1$ & $<1$ & $<1$ \\
\hline La & $<1$ & $<1$ & $<1$ & $<1$ & $<1$ & $<1$ \\
\hline Hf & $<1$ & $<1$ & $<1$ & $<1$ & $<1$ & $<1$ \\
\hline $\mathbf{P b}$ & 7 & 7 & 8 & 6 & 7 & 7 \\
\hline Th & 3 & 6 & 5 & 4 & 4 & 5 \\
\hline $\mathbf{U}$ & 3 & 2 & 4 & 3 & 4 & 3 \\
\hline
\end{tabular}




\subsection{Some Technical Considerations}

Chemical analyses of crude Marwit Rod El Leqah quartz samples showed to match the specifications of many advanced applications like aluminum alloys $\left(98 \% \mathrm{SiO}_{2}, 0.02 \% \mathrm{Fe}_{2} \mathrm{O}_{3}, 0.3 \% \mathrm{CaO}\right.$ and $\left.400 \mathrm{ppm} \mathrm{Ti}\right)$, ferrosilicon alloys ( $98 \% \mathrm{SiO}_{2}, 0.4 \% \mathrm{~A}_{2} \mathrm{O}_{3}, 0.2 \%$, each of $\mathrm{Fe}_{2} \mathrm{O}_{3}, \mathrm{CaO}$, and $\mathrm{MgO}$ ), silicon carbide (99.50\% to $99.75 \% \mathrm{SiO}_{2}$, $0.04 \%$ to $0.05 \% \mathrm{Al}_{2} \mathrm{O}_{3}, 0.05 \%$ to $0.1 \% \mathrm{Fe}_{2} \mathrm{O}_{3}$ and $1.10 \% \mathrm{CaO}+\mathrm{MgO}$ ), and electrode industry ( $97.5 \%$ to $99.5 \%$ $\mathrm{SiO}_{2}, 0.05 \% \mathrm{Fe}_{2} \mathrm{O}_{3}$ and $0.03 \%$ (max.)S. Yet, these chemical specifications do not match the requirements of high technical applications like silicon metal $\left(99.67 \% \mathrm{SiO}_{2}, 0.08 \% \mathrm{Al}_{2} \mathrm{O}_{3}\right)$, silicon for solar cells $\left(>99.8 \% \mathrm{SiO}_{2}\right)$, electronics (99.8\% $\mathrm{SiO}_{2}, 0.05 \% \mathrm{Al}_{2} \mathrm{O}_{3}$ ) and optical applications (99.7\% - 99.8\% $\mathrm{SiO}_{2}, \mathrm{Fe}_{2} \mathrm{O}_{3} \leq 0.014 \%, \mathrm{Al}_{2} \mathrm{O}_{3} \leq$ $0.075 \%)$.

\section{Conclusion}

The relative low $\mathrm{SiO}_{2}$ content in Marwit Rod El Leqah quartz body (99.57\%) was classified this deposit as medium purity quartz (with about $4250 \mathrm{ppm}$ impurities). The accepted level for high purity quartz was $>99.80 \%$ $\mathrm{SiO}_{2}$ (with less than $50 \mathrm{ppm}$ impurities). Accordingly, the quartz deposits of this area did not match the chemical requirements for the high technical applications like the production of metallurgical, solar, and electronic silicon metal.

\section{Recommendation}

The applying of the proper beneficiation techniques to separate and remove as possible the present solid impurities in Marwit Rod El Leqah quartz is a must to upgrade the quality of the sample to match the specifications required for high technical applications.

\section{References}

[1] Haus, R. (2005) High Demands on High Purity-Processing of High Purity Quartz and Diatomite. Industrial Minerals, 10, 62-67.

[2] Moore, P. (2005) High Purity Quartz. Industrial Minerals, 8, 54-57.

[3] Blankenburg, H.J., Götze, J. and Schulz, H. (1994) Quarzrohstoffe. Deutscher Verlagfür Grundstoffindustrie. LeipzigStuttgart, 296.

[4] Dal Martello, E., Tranell, G., Gaal, S., Raaness, O.S., Tang, S.K. and Arnberg, L. (2011) Study of Pellets and Lumps as Raw Materials in Silicon Production from Quartz and Silicon Carbide. Metallurgical and Materials Transactions B, 42 , 939-950. http://dx.doi.org/10.1007/s11663-011-9529-y

[5] Haus, R. (2005) High Demands on High Purity-Processing of High Purity Quartz and Diatomite. Industrial Minerals, 62-67.

[6] Harben, P.W. (2002) The Industrial Mineral Handy Book-A Guide to Markets, Specifications and Prices. 4th Edition, Industrial Mineral Information, Worcester Park, 412.

[7] Heaney, P.J., Prewitt, C.T. and Gibbs, G.V. (1994) Silica-Physical Behavior, Geochemistry and Materials Applications. Reviews in Mineralogy, Mineralogical Society of America, Washington, 29, 606.

[8] Hyrsl, J. and Niedermayr, G. (2003) Magic World: Inclusions in Quartz. Bode Verlag, Haltern, 240.

[9] Roedder, E. (1984) Fluidinclusions. Reviews in Mineralogy, 12, 644.

[10] Rykardt, R. (1995) Quarz-Monographie. 2nd Edition, Ott Verlag, Thun,.

[11] Larsen, R.B., Polvé, M. and Juve, G. (2000) Granite Pegmatite Quartz from Evje-Iveland: Trace Element Chemistry and Implications for High-Purity Quartz Formation. Norges Geologiske Undersøkelse, 436, 57-65.

[12] Geo Surv Egypt and Acadsci Res \& Tech (1992) Study of Quartz and Quartzite Deposits in the Eastern Desert, Egypt. Internal Report No. 22. 